Japan. Jour. Crop Sci. 58(2) : 204-211 (1989)

\title{
Ultrastructure of Inoculated Anthers in Relation to the Frequency of Induction of Pollen Callus in Anther Culture of Oryza sativa L.*
}

\author{
Hiroshi Nakano** and Eizo MaEDa \\ (Faculty of Agriculture, Nagoya University, Chikusa-ku, Nagoya 464, Japan) \\ Received September 2, 1988
}

\begin{abstract}
The formation of pollen callus was induced when rice anthers, which contained microspores in the mid-uninucleate and late-uninucleate stage, were cultured. The ultrastructure of the microspores was also examined in the anthers in vivo. The amount of mitochondria and rough endoplasmic reticulum in the microspores increased and their nuclei and nucleoli enlarged from the early stage to the mid-uninucleate and late-uninucleate stages, resulting in an increase of the cell activities. Morphology of plastids changed from ring-shaped plastids and plastids containing starch grains to ordinary proplastids. Microbodies also appeared in the microspores. Cell organelles in the tapetal cells of the anther wall gradually underwent degenerative changes during this period. After the favorable stage for anther inoculation in vitro, the pollen cells showed the first pollen mitosis and the vegetative cells started to differentiate into mature storage cells which accumulated starch grains. However, the ultrastructure of the tapetal cells did not change significantly during this period. Based on these results, it was suggested that the above-mentioned ultrastructural changes reflected the ability of the rice pollen cells to undergo dedifferentiation in anther culture.
\end{abstract}

Key words : Anther Culture, Oryza sativa L., Rice, Ultrastructure.

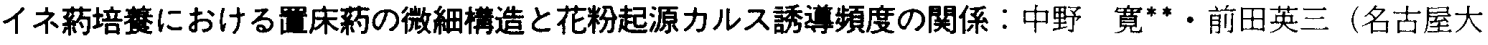
学農学部)

要 旨：1核期中期から後期の小胞子を含むイネ葯を置床し培責した時, 花粉が脱分化し, 花粉起源力ルスの 誘導が可能であった。そこで，この脱分化可能な発育段階にある葯壁と花粉細胞の特徵を微細構造の面から 明らかにしようとした。より末熟な 1 核期前期の小胞子に比べ，この時期の花粉細胞ではミトコンドリアが 增加し，粗面小胞体が発達し，核や核小体も大きくなっていた。これは，この発育段階において，花粉細胞 の代謝活性が高まる事を示していた。また，プラスチドは，1核期前期に見られたような釣鐘状プラスチドや デンプン粒を有する小プラスチドは消失し，通常のプロプラスチドに変化した。また，マイクロボディが現 われたのもこの時期であった。一万，葯壁では，この時期からタペート細胞の崩壊が始まった。次に，移植 適期の 1 核期中後期を過ぎると，花粉細胞は花粉分裂を行いささらに栄湌核細胞はデンプ粒を蓄積し貯蔵 細胞にと変化し始めた。しかし，この期間，タペート細胞の方は，移植適期に比べて微細構造面で特に変化 を示さなかった。以上の結果から，上述のような花粉およびタペート細胞の微細構造変動のなんらかが，葯 の発育に伴う花粉細胞の葯培養条件下での脱分化能の消長と結びついている可能性があると推察された。 キーワード：イネ，花粉，微細構造，葯培責.
\end{abstract}

Anther culture and regeneration of haploid plants have been previously reported in rice plants $^{9,13)}$. When anthers with uninucleate microspores were inoculated on culture medium, the induction frequency of pollen callus and embryoids was high ${ }^{9,14}$; however, there have been few studies on the physiological and cytological characteristics of microspores at this stage in relation to their ability to undergo in vitro dedifferentiation.

\footnotetext{
* A part of this investigation was presented at 165th meeting (April, 1978) of the Crop Science Society of Japan.

** Present Address : Tropical Agriculture Research Center, Okinawa Branch, Ishigaki, Okinawa 907-01, Japan.
}

After inoculating rice anthers of various ages, we examined the induction frequency of pollen callus and observed the ultrastructural changes associated with the development of pollen cells and anther wall tissues of field grown rice. This paper presents the ultrastructural features of pollen cells and anther wall tissues in the anthers in the in vivo developmental stage suitable for the rice pollen callus formation in vitro.

\section{Materials and Methods}

Rice panicles (cultivar IARI 5995) were harvested while still enclosed within the sheath of flag leaves. The panicles were sterilized in $1 \%$ chlorox solution for $10 \mathrm{~min}$ and rinsed 
four times in sterile distilled water. In rice, six anthers in a floret show similar anther lengths and the anther length correlates closely with the pollen development ${ }^{23}$. Also in the cultivar used in this study, the standard error of the length of six anthers was very small $(0.010 \sim 0$. $034 \mathrm{~mm}$ throughout the pollen development from the pollen mother cell stage to the binuclear stage) and they contained pollen grains of similar developmental stages. So four or five anthers in a floret were planted on agar medium in a test tube and the length of the others was measured and recorded at 0.125 $\mathrm{mm}$ intervals. The developmental stage of the pollen grains was cytologically examined in twenty anthers for each interval.

The culture medium, the same as that employed by Guha-Mukherjee ${ }^{9)}$, comprised Bleydes' constituents supplemented with $3 \%$ sucrose, $0.9 \times 10^{-5} \mathrm{M} 2$, 4-dichlorophenoxyacetic acid (2, 4-D), $1.1 \times 10^{-5} \mathrm{M}$ indoleacetic acid (IAA), $0.47 \times 10^{-5} \mathrm{M}$ kinetin, $0.1 \%$ yeast extract and $15 \%$ coconut milk. The $\mathrm{pH}$ was adjusted to 5.8 and the cultures were maintained at $30^{\circ} \mathrm{C}$ in the dark.

For electron microscopy, anthers of field grown rice were fixed in $4 \%$ glutaraldehyde in $\mathrm{pH} 7.2,0.1 \mathrm{M}$ phosphate buffer at $4^{\circ} \mathrm{C}$ for $4 \mathrm{hr}$. They were post-fixed in $2 \%$ osmium tetroxide in the same buffer at $4^{\circ} \mathrm{C}$ for $10 \mathrm{hr}$. After dehydration through an ethanol series and propylene oxide, they were embedded in Epon 812 or Spurr's low viscosity resin. Ultrathin sections were stained with uranyl acetate and lead acetate and examined with a Hitachi HU-12A electron microscope.

\section{Results}

\section{Induction frequency of callus tissues}

Pollen cells underwent dedifferentiation into multicellular pollen grains and gave rise to globular-shaped callus in cultured anthers. Cell proliferation in the anther wall could not be histologically detected, indicating that the callus tissues originated only from the pollen cells.

The uninucleate microspore stage in rice can be subdivided into four successive stages based on pollen grain shape, according to Kihara and Hirayoshi ${ }^{12)}$. The first stage is the contraction phase of the early-uninucleate stage, in which microspores shrink and the outer wall is formed. It is followed by the

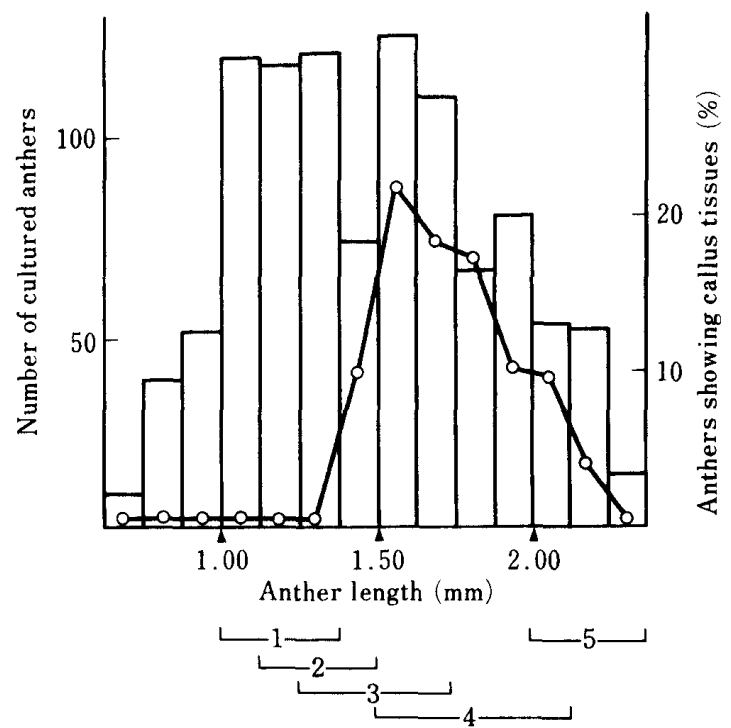

Fig.1. Relation between the induction of callus tissues in vitro and developmental stage of pollen cell at the time of inoculation in rice anther culture. Histogram represents the number of cultured anthers. Curve represents the percentage of anthers on which callus tissues were induced about 60 days after inoculation. The range of each developmental stage of the pollen cell was represented in relation to the anther length, contraction phase of early-uninucleate stage (1), recovery phase of early-uninucleate stage (2), mid-uninucleate stage (3), late-uninucleate stage (4) and binuclear pollen (5).

recovery phase of the early-uninucleate stage in which the shrinking microspores become spherical. The next stage is the mid-uninucleate stage in which the microspores again shrink and rapidly enlarge. Then, they assume again a spherical shape in the late-uninucleate stage preceding pollen mitosis.

Callus tissues were induced in vitro when anthers with a length ranging from $1.375 \mathrm{~mm}$ to $2.25 \mathrm{~mm}$ were inoculated (Fig.1). The anthers of the minimum length contained the microspores of the recovery phase of the early-uninucleate stage or the mid-uninucleate stage at the inoculation time and the anthers of the maximum length contained the pollen grains of the late-uninucleate stage or the binuclear stage. Maximum response was obtained with anthers whose length ranged from $1.50 \mathrm{~mm}$ to $1.625 \mathrm{~mm}$. This range corresponded to the transitional period from the 
Table 1. Frequency of dehiscence and necrosis of cultured anthers.

\begin{tabular}{lcc}
\hline & $\begin{array}{c}\text { Anther shorter } \\
\text { than } 1.375 \mathrm{~mm}^{1)}\end{array}$ & $\begin{array}{c}\text { Anther measuring } \\
1.375 \mathrm{~mm} \text { or more }\end{array}$ \\
\hline Dehiscence & 2 & 126 \\
Absence of dehiscence & 186 & 63 \\
\hline Necrosis of two thecae & 14 & 30 \\
Necrosis of one theca & 9 & 45 \\
Absence of necrosis & 165 & 114 \\
\hline Total number of anthers observed ${ }^{2)}$ & 188 & 189 \\
\hline 1 Callus tissues were not formed in anthers shorter than $1.375 \mathrm{~mm}$ at the time of inculation. \\
2 Frequency was checked 65 to 85 days after inoculation.
\end{tabular}

mid-uninucleate stage to the late-uninucleate stage.

When immature anthers shorter than 1.375 $\mathrm{mm}$ were inoculated, no callus tissues were induced on these anthers. Most of them did not become necrotic and very few exhibited signs of dehiscence in vitro (Table 1). Moreover, when longer anthers were inoculated and callus tissues were induced on a theca of the anthers, another theca frequently became necrotic. These results suggest that the induction of pollen callus was closely associated with the anther wall age and its metabolism state.

Ultrastructure of pollen cells and anther wall

In the recovery phase of the early-uninucleate stage, the cytoplasm of the pollen cells was prominent with small vacuoles sparsely distributed and also very small vesicles, some of which were multivesicular bodies (Fig.2 A, B). The nuclei and nucleoli were smaller than those at the later stages. Many spherical granules with double limiting membranes were observed, corresponding to protomitochondria or proplastids. No mitochondria with distinct cristae were observed. Ring-shaped proplas- tids and small plastids containing starch grains were observed at this stage as well as at earlier stages. The anther wall is composed of four cell layers, i.e., the epidermis, two inner cell layers and the tapetum. Only tapetal cells in these tissues showed dynamic ultrastructural changes reflecting the growth process of the anther. Furthermome, since it is considered that the tapetal cells are more directly related to the development of pollen cells than the other tissues, the ultrastructural changes of the tapetal cells were observed in vivo. In the recovery phase of the early-uninucleate stage, the tapetal cells (Fig.2 C, D) contained welldeveloped rough endoplasmic reticulum, occasionally oriented in parallel arrays. Mitochondria, proplastids with plastglobuli, Golgi bodies and vesicles containing fibrillar inclusions were also observed. Ubisch bodies had been formed on the tapetal surface facing the anther cavity.

In the period favorable for culture, which corresponded to the mid-uninucleate stage and the late-uninucleate stage, the pollen cells (Fig. $2 \mathrm{E}, \mathrm{F}$ ) were highly vacuolated and the

Fig.2. Ultrastructure of developing pollen cells and tapetal cells of field grown rice plants. Microspores (A and B) and tapetal cells ( $\mathrm{C}$ and $\mathrm{D}$ ) in the recovery phase of the earlyuninucleate stage. Microspores (E and F) in the mid-uninucleate stage. A : Large number of small vacuoles and a few lipid droplets in the spherical microspore. $\times 5100, \mathrm{~B}$ : Multivesicular bodies, proplastids containing starch grains and small granules with double limiting membranes (arrow). $\times 24000, \mathrm{C}:$ Well-developed rough endoplasmic reticulum in the cytoplasm and Ubisch bodies on the surface of tapetal cell. $\times 9200, \mathrm{D}:$ Intact ordinary plastids, vesicles with fibrillar inclusions (an arrow) and rough endoplasmic reticulum oriented in parallel arrays (asterisk) $\times 15000, \mathrm{E}:$ Large central vacuole and many mitochondria have been formed in the shrinking microspore. $\times 5200, \mathrm{~F}:$ Microbodies and proplastids without starch grains. Rough endoplasmic reticulum developed. $\times 12000$, Abbreviations for Fig.2 and $3: \mathrm{G}$; Golgi body, I ; intine, L ; lipid droplet, $\mathrm{Mb}$; microbody, Mt ; mitochondrion, MVB ; multivesicular body, $\mathrm{N}$; nucleus, O ; osmiophilic droplet, $\mathrm{P}$; plastid, RER; rough endoplasmic reticulum, S; starch grain, $\mathrm{U}$; Ubisch body, $\mathrm{V}$; vacuole. 

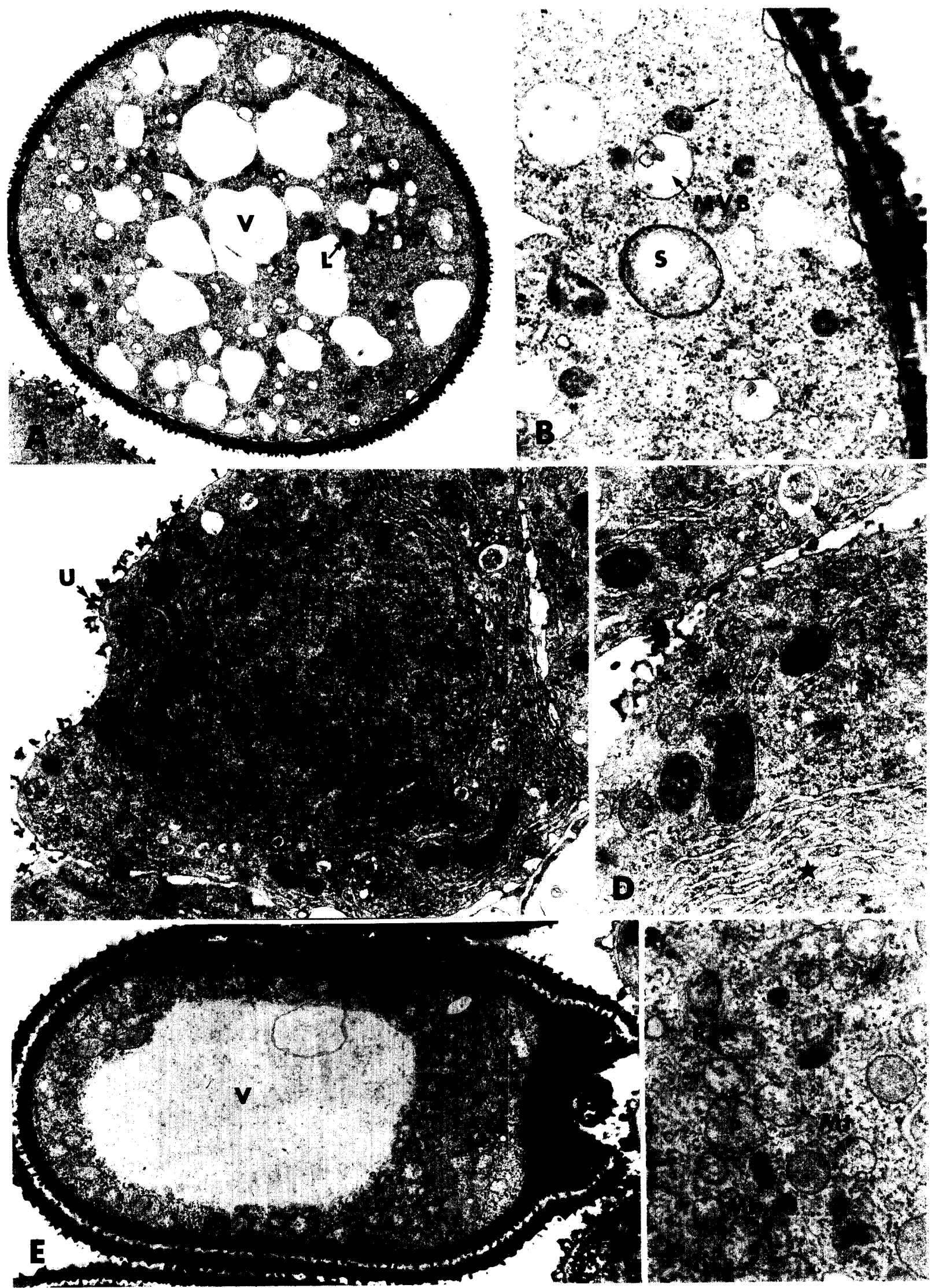

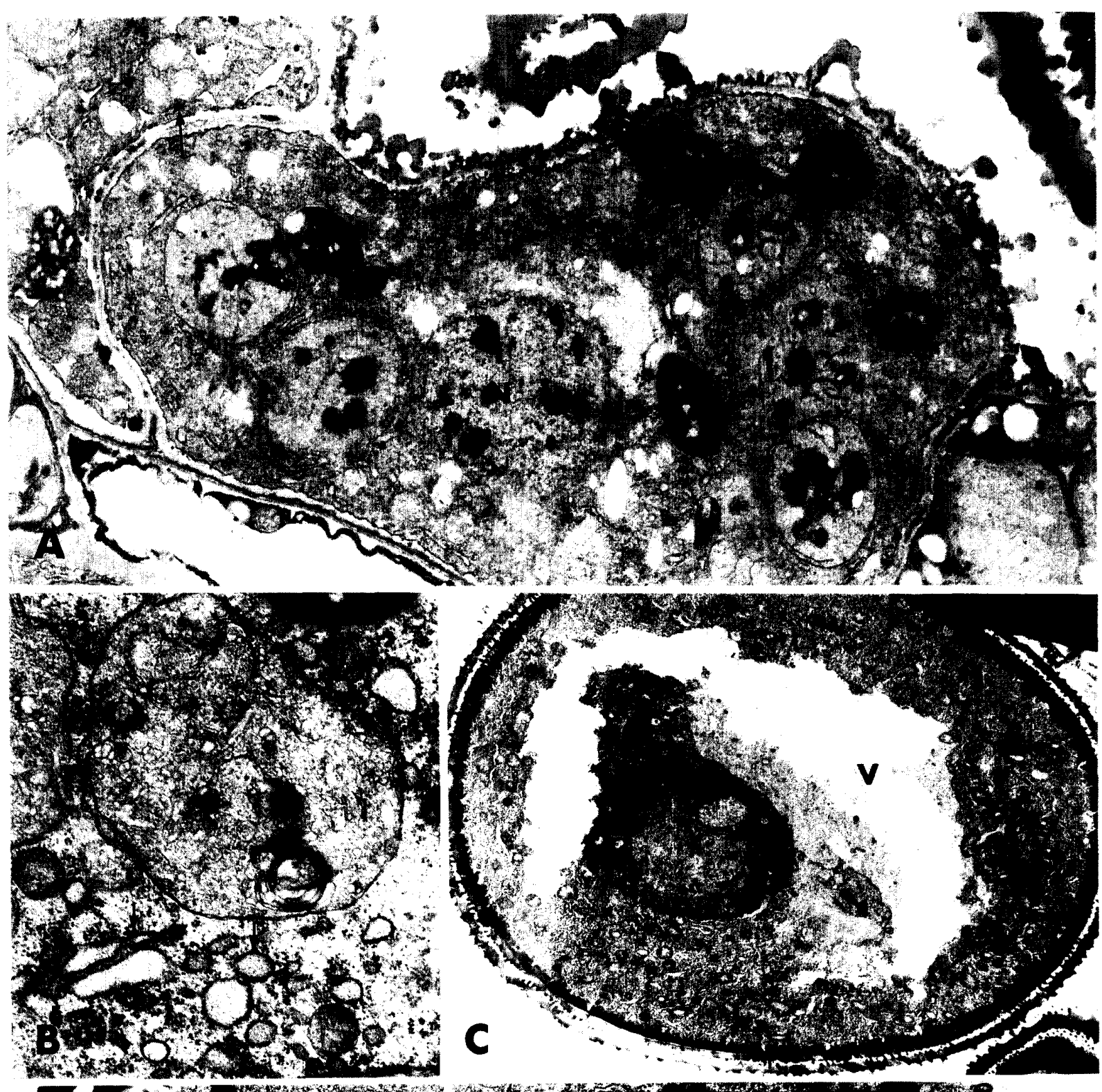

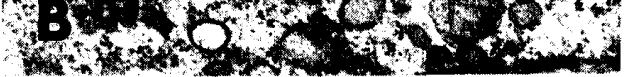

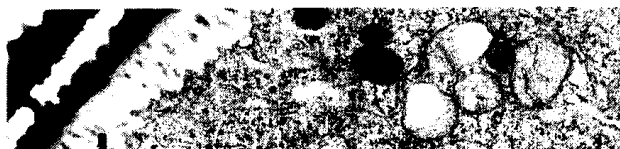

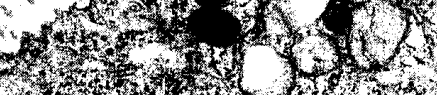

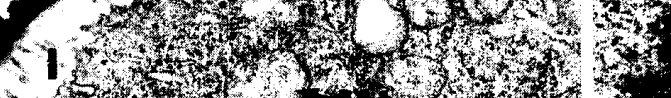

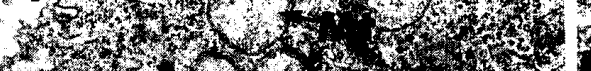

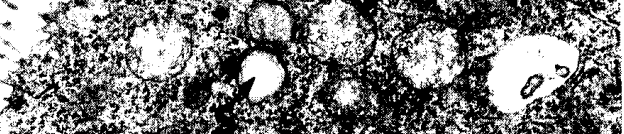

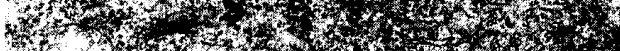

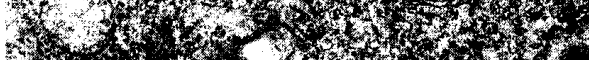

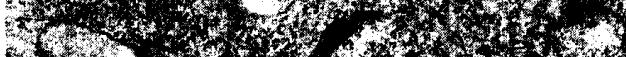
K.

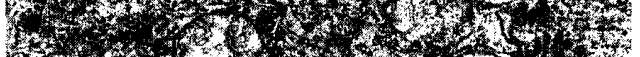

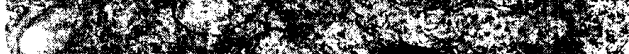
(.) 30.

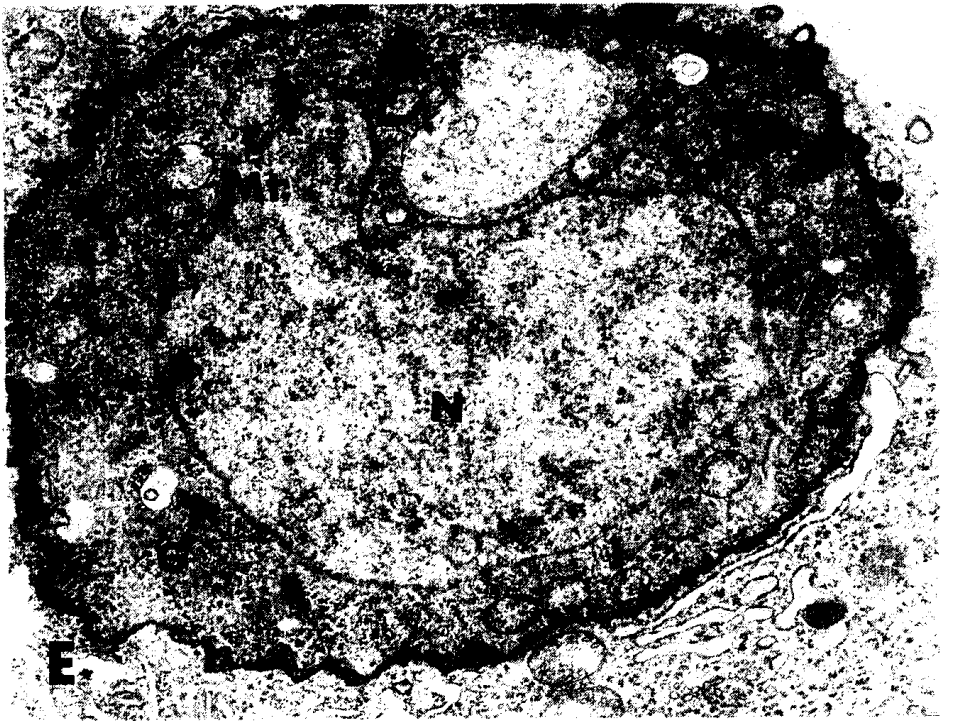


small vesicles disappeared from their cytoplasm. Their nuclei and nucleoli were enlarged. Although ordinary proplastids were observed, ring-shaped proplastids and small plastids containing starch grains disappeared. Numerous mitochondria and some microbodies appeared and the rough endoplasmic reticulum developed. The organelles in the tapetal cells (Fig. $3 \mathrm{~A}, \mathrm{~B}$ ), on the other hand, underwent degenerative changes. The rough endoplasmic reticulum was fragmented into small vesicles on the outer surface of which ribosomes were bound. The matrix in these vesicles became more electron-dense along with the degeneration of the tapetal cells. Large osmiophilic droplets occurred in the cytoplasm and small osmiophilic droplets were occasionally observed in the cisternae of the endoplasmic reticulum. Although the mitochondria still remained, proplastids changed into large plastids with the degeneration of the membrane system.

The ultrastructure of the vegetative cells, immediately after the first pollen mitosis, was similar to that of the pollen cells in the period favorable for culture. Thereafter the generative cell was detached from the intine and moved towards the center of the pollen grain. In the vegetative cells (Fig. $3 \mathrm{C}, \mathrm{D}$ ) at this time, the cytoplasm increased while the central vacuole became smaller in size. Rough endoplasmic reticulum was more developed and the number of mitochondria further increased. Starch grains began to accumulate in the plastids. Mitochondria, proplastids, Golgi bodies, lipid droplets and rough endoplasmic reticulum were present in the generative cells (Fig. $3 \mathrm{E}$ ). The tapetal cells continued to undergo degenerative changes.

\section{Discussion}

In this study, pollen cells in the transitional period from the mid-uninucleate stage to the late-uninucleate stage frequently dedifferentiated in in vitro anther culture. This observation was in agreement with the findings reported in the previous papers ${ }^{3,5,10)}$.

In the rice microspores in the period favorable for culture, the small plastids containing starch grains and ring-shaped plastids disappeared and ordinary proplastids appeared. The ring-shaped plastid, which had been observed in callus of Dianthus caryophyllus ${ }^{1)}$, was assumed to be an inclusion in quiescent cells. Therefore, the disappearance of such structures suggested cell activation along with the enlargement of the nucleus and nucleolus and the development of the rough endoplasmic reticulum which are involved in the RNA and protein synthesis respectively. Numerous mitochondria also appeared reflecting an increase in respiration. It was assumed that the cytological activation of the pollen cells promoted their dedifferentiation in vitro, as cell-dedifferentiation is usually accompanied with such activation in higher plants ${ }^{17,20,24)}$. Microbodies also appeared at this stage. Although their function in the microspores has not yet been elucidated, they have been observed during cell activation for shoot formation in $\mathcal{N}$. tabacum callus $^{18)}$.

We observed a positive correlation among anther browning, dehiscence of theca and the induction of callus tissues as reported in a previous study with rice and other plants ${ }^{2)}$. The tapetal cells were meristematic in the recovery phase of the early-uninucleate stage and had not degenerated. Their cytoplasmic contents started to break down at the mid-

Fig.3. Ultrastructure of developing pollen cells and tapetal cells of rice plant. Tapetal cells (A and $B$ ) in the mid-uninucleate stage and pollen cells ( $C$ to $E$ ) in the binuclear stage. A : Degenerating tapetal cells contain large osmiophilic droplets and degenerating plastids. Small osmiophilic droplets are seen in the cisternae of the endoplasmic reticulum (arrow) $\times 13000$, B : Rough endoplasmic reticulum was transformed into small vesicles (arrows) to which ribosomes were attached. $\times 21000, \mathrm{C}:$ Generative cell detached from the intine of the vegetative cell with increasing amount of cytoplasm. $\times 2900, \mathrm{D}:$ Rough endoplasmic reticulum developed further and the number of mitochondria increased. Starch grains accumulated in plastids in the vegetative cell. $\times 9700, \mathrm{E}:$ Enlarged view of a generative cell (Fig. 3C). It contains a nucleus, mitochondria, Golgi bodies, lipid droplets, proplastids without starch grains and rough endoplasmic reticulum. $\times 9700$. 
uninucleate and late-uninucleate stage as other plants ${ }^{16)}$. When young anthers as those in the early-uninucleate stage were inoculated, anther browning and dehiscence was scarcely observed. When older anthers were inoculated and callus tisses were induced on a dehisced theca, the tapetal cells were digested and disappeared ${ }^{11}$. These facts suggest that the in vivo initiation of autolysis in the tapetal cells is also required for the induction of sporophytic divisions of microspores in anther culture. It is conceivable that the tapetal cells of the young anthers were not digested and they did not act as nutrients for the pollen cells in vitro. Nurse function of the anther wall was demonstrated through the effect of the metabolites of anther tissues in isolated microspore culture in rice ${ }^{4)}$ and other plants ${ }^{6,15)}$.

In this study, callus tissues were scarcely formed in vitro on anthers in which the pollen cells may have reached the binuclear stage before inoculation. In the binuclear stage, starch grains began to accumulate in the vegetative cell, leading to its differentiation into a storage cell. Therefore, the inability of the vegetative cell to dedifferentiate in vitro may be due to the progress in differentiation into mature storage cells. The onset of starch formation marked the end of the period favorable for anther culture also in Datura innoxia ${ }^{19}$. On the other hand, no distinctive ultrastructural changes were recognized in the tapetal cells at the end of the period favorable for culture.

This study suggests that the ability of the pollen cells to undergo dedifferentiation in vitro was related to their intrinsic nature and it was influenced by the degeneration of the tapetal cells. The ultrastructure of the pollen cells was examined at an optimum stage for anther culture in $D$. innoxia ${ }^{8,19)}$, in $\mathcal{N}$. tabacum $^{7,21,22)}$ and Hyoscyamus niger ${ }^{17)}$ before and after the first pollen mitosis. Vazart reported the presence of incomplete separation between the vegetative cells and the generative cells in a few pollen grains, as a particular ultrastructural characteristic related to their ability to undergo dedifferentiation in vitro ${ }^{21,22)}$. However, they also observed ultrastructural changes related to cell activation of the pollen cells in the optimum stage for culture ${ }^{7,8,19,21,22)}$. The uninucleate stage is a period favorable for anther culture in many other angiosperms. It is necessary to study other plants in order to identify characteristic ultrastructural particularities of pollen cells suitable for their dedifferentiation and determine the role of the tapetal cells in vitro.

\section{Acknowledgment}

The authors acknowledge with gratitude the generous gift of rice seeds from Dr. E.A. Siddiq of Indian Agricultural Research Institute, India and honorary Professor Dr. T. Watabe of Kyoto University, Japan. The authors express their appreciation to Dr. N. Yamada for his helpful advice during the course of this study.

\section{References}

1. Bornman, C.H. 1974. Cytodifferentiation in tissue culture. In Tissue Culture and Plant Science (Ed.) H.E. Street, Academic Press, London and New York. $43-70$.

2. Cai, X.S. 1981. The relationship between anther browning and callus formation in tobacco, rice and asparagus anther culture. J. Agric. Res. China $30: 121-131$.

3. Chen, C.C. 1977. In vitro development of plants from microspores of rice. In vitro $13: 484-489$.

4. —_, R.F. Wang, W.Z. Tian, Q.X. Zuo, S. W. Zheng, D.Y.Lu and G.H.Zhang 1980. Studies on rice pollen culture and plantlet induction. Acta Genet. Sin. $7: 46-54$.

5. - and Y.-H. Wu 1983. Segmentations in microspores of rice during anther culture. Proc. Natl. Sci. Counc. B7 : $151-157$.

6. Debergh, P. and C. Nitsch 1973. Premiers résultats sur la culture in vitro de grains de pollen isolés chez la Tomate. C.R. Acad. Sci. Paris D276 : 1281-1284.

7. Dunwell, J.M. and N.Sunderland 1974. Pollen ultrastructure in anther cultures of Nicotiana tabacum. I. Early stages of culture. J. Exp. Bot. 25 : $352-361$.

8. - - 1976. Pollen ultrastructure in anther cultures of Datura innoxia. I. Division of the presumptive vegetative cell. J. Cell Sci. 22 : 469 -480 .

9. Guha-Mukherjee, S. 1973. Genotypic differences in the in vitro formation of embryoids from rice pollen. J. Exp. Bot. 24 : 139-144.

10. $\mathrm{Hu}, \mathrm{H}$. and S. Hao 1980. Some advances in anther culture technique of maize and rice. In Plant Cell Cultures: results and perspectives (Eds.) Sala, F. et al., North-Holland Biochemical Press, Elsevier, Amsterdam. 87-88.

11. Liang, H.-M., H.-X. Zhong and X.-Y. Yu 1980. 
Preliminary studies on conditions for initiation of dedifferentiation of pollen cells and the changes of anther wall tissues in anther cultures. Acta Phytophysiol. Sin. $6: 19-28$.

12. Kihara, H. and I. Hirayoshi 1942. Entwicklung des pollenkorns bei Oryza sativa L. Agric. Hortic. Tokyo $17: 685-690^{*}$.

13. Niizeki, H. and K. Oono 1968. Induction of haploid rice plant from anther culture. Proc. Jpn. Acad. 44: 554-557.

14. _— 1971. Rice plants obtained by anther culture. Colloq. Int. Cent. Natl. Rech. Sci. $193: 251-257$.

15. Nitsch, C. and B. Norreel 1973. Effet d'un choc thermique sur le pouvoir embryogène du pollen de Datura innoxia cultivé dans l'anthère ou isolé de l'anthère. C.R. Acad. Sci. Paris D 276 : 303-306.

16. Raghavan, V. 1981. A transient accumulation of poly (A)-containing RNA in the tapetum of Hyoscyamus niger during microsporogenesis. Dev. Biol. 81 : $342-348$.

17. Reynolds, T.L. 1984. An ultrantructural and stereological analysis of pollen grains of Hyoscyamus niger during normal ontogeny and induced embryogenic development. Am. J. Bot. 71: 490 $-504$.

18. Ross, M.K., T.A. Thorpe and J.W. Costerton 1973. Ultrastructural aspects of shoot initiation in tobacco callus cultures. Am. J. Bot. 60 : 788-795.
19. Sangwan-Norreel, B.S. 1978. Cytochemical and ultrastructural peculiarities of embryogenic pollen grains and of young androgenic embryos in Datura innoxia. Can. J. Bot. 56 : 805-817.

20. Tran Thanh Van, M. and A. Chlyah 1976. Différenciation de boutons floraux, de bourgeons Végétatifs, de racines et de cal à partir de l'assise sous-épidermique des ramifications florales de Nicotiana tabacum Wisc. 38. Etude infrastructurale. Can. J. Bot. 54 : 1979-1996.

21. Vazart, B. 1971a. Première division haploide et formation de la cellule génératrice dans le pollen de tabac. Ann. Univ. A.R.E.R.S., Reims, France $9: 179-187$.

22. —_ 1971b. Infrastructure de microspores de Nicotiana tabacum L. susceptibles de se développer en embryoides après excision et mise en culture des anthères C.R. Acad. Sci. Paris D272 : 549 -552 .

23. Yamada, N. 1972. Studies on the developmental physiology in rice pollen. $\mathbf{I}$. The metabolic patterns connected with the structural changes in developing pollen. Proc. Crop Sci. Soc. Japan 41 : $320-334^{* *}$.

24. Yeoman, M.M. 1970. Early development in callus cultures. Int. Rev. Cytol. 29 : 383-409.

* In Japanese with German summary.

** In Japanese with English summary. 